\title{
Evidence for liver cell proliferation during fatal acute liver failure
}

\author{
MILENA MILANDRI,* J GAUB, AND L RANEK \\ From Medical Department A, Division of Hepatology, Rigshospitalet, Copenhagen, Denmark
}

SUMMARY Liver cell regeneration was assessed by determining the mitotic index and the frequency of liver cells with interploid DNA values in livers from patients dying from fulminant hepatitis. For comparison, the same parameters were determined in patients with uncomplicated hepatitis. We found comparable levels of regeneration in the two groups, indicating that the rate of liver cell destruction is a major determinant in the prognosis of acute liver failure. Accordingly, measures to prevent liver cell necrosis seem at least as important as stimulation of regeneration. Judged from available experimental evidence, substances with documented hepatotrophic effect in animals, such as insulin and glucagon, may therefore not be effective in acute liver failure unless the patient has impaired secretion of these substances.

Acute liver failure (ALF) due to viral or toxic hepatitis carries a mortality of around $80 \%$.

Different kinds of therapy have been tried without success, most of which attempt to correct the intoxication, which is believed to be of pathogenetic importance in hepatic coma.

As the basic defect in liver insufficiency is a lack of liver cells, it would be relevant to look for substances which stimulate liver cell proliferation. In animal experiments insulin and glucagon have been shown to be important for the maintenance and restoration of the liver cell mass. ${ }^{1-3}$ It seems appropriate therefore to treat patients with acute liver failure with insulin and glucagon. ${ }^{4}$

One important point, however, must be considered first-namely, whether the declining liver cell mass is mainly due to lack of regeneration, or to an extensive destruction of liver cells which exceeds liver cell regeneration. If this is the case, efforts should be aimed at halting liver cell destruction.

As far as we know, liver cell regeneration in the human liver during acute liver failure has not been documented. We have therefore determined the number of liver cells synthesising DNA-that is, having a DNA content between mean ploidy values -and counted liver cell mitoses in liver biopsies from patients with acute liver failure.

-Address for correspondence: Milena Milandri, Medical Department. A, Division of Hepatology, Rigshospitalet, 9 Blegdamsvej, DK-2100 Copenhagen, Denmark.

Received for publication 9 November 1979

\section{Methods}

PATIENTS

Liver biopsies were taken during coma or immediately after death from seven patients with acute liver failure-that is, patients with no previous liver disease and acute impairment of liver function leading to hepatic coma and death. Two patients (nos. 1 and 2) were classified as having type $A$ hepatitis, two (nos. 3 and 6) had non-A non-B hepatitis, and one (no. 7) had type B hepatitis, with superimposed drug hepatitis. The controls comprise biopsies from one normal liver, one patient with type B hepatitis recovering from acute liver failure (no. 15), and six patients with acute hepatitis. Two of these (nos. 9 and 10) had type A hepatitis, three (nos. 11, 13, and 15) had type B hepatitis, and two had drug hepatitis from halothane (no. 12) and disulfiram (no. 14) respectively. Three of these latter patients subsequently died: death was due to surgical complications (no. 12), to superimposed drug hepatitis during remission (no. 13), and to abrupt deterioration after clinical improvement (no. 14). A postmortem liver biopsy from patient no. 13 is included in the acute liver failure group.

\section{TECHNIQUES}

Liver biopsies were fixed in $4 \%$ formaldehyde and paraffin sections cut at $12 \mu \mathrm{m}$. The slides were stained with Feulgen for DNA and Naphthol Yellow $\mathrm{S}$ for protein. The counterstaining with Naphthol Yellow S was done in order to facilitate orientation 
Fig. 1 DNA frequency-histogram of parenchymal liver cells from rats 28 hours after sham operation (top) and 28 hours after partial hepatectomy (bottom).

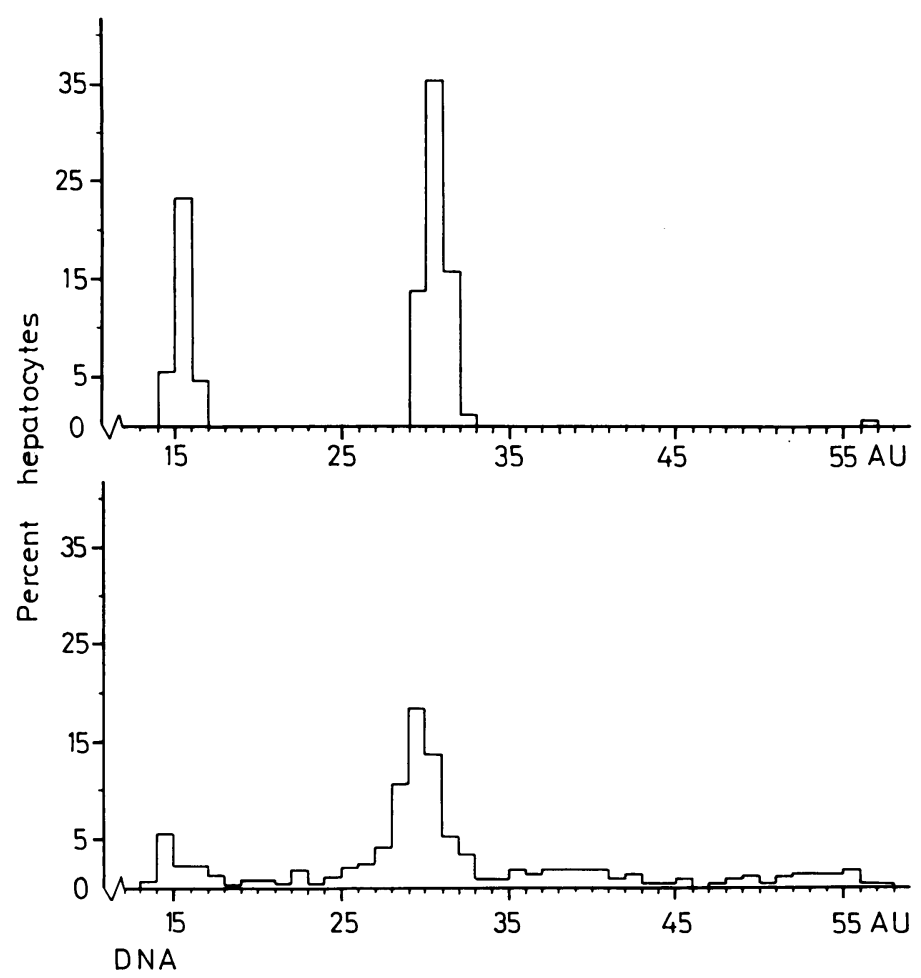

in the section and does not interfere with the quantitative Feulgen staining of DNA. ${ }^{5}$ Measurement of nuclear DNA was performed at $570 \mathrm{~nm}$ with a Zeiss UMSP I microspectrophotometer. Intact hepatocytes were selected randomly, avoiding the edges of the section. Partially cut nuclei were excluded by focusing and comparing the levels of the upper and lower nuclear poles to those of the section surfaces. The mean number of nuclei scanned for each biopsy was 148 (range 33-289). The number available was in some cases limited because of pigment in the liver cells, a low number of hepatocytes, or the small size of the biopsy.
Analysis of frequency-histograms was performed according to Barfod. ${ }^{6}$

Mitotic figures (meta-anaphase) were counted in the Feulgen stained slides and expressed per 1000; whenever possible, mitotic index was based on count of 10000 hepatocytes.

VALIDATION OF METHOD

A possible error in our method would be the selection of partially cut nuclei for determination of DNA contents. If a tetraploid or octaploid nucleus in the section is partially cut, the measured DNA content will correspond to values of an S-phase diploid or

Table 1 Clinical data and regenerative indices of hepatocytes from ALF patients

\begin{tabular}{|c|c|c|c|c|c|c|c|c|c|}
\hline \multirow[b]{2}{*}{$\begin{array}{l}\text { Patient } \\
\text { no. }\end{array}$} & \multirow[b]{2}{*}{$\begin{array}{l}\text { Sex/age } \\
(y r)\end{array}$} & \multirow{2}{*}{\multicolumn{2}{|c|}{$\begin{array}{l}\text { Duration of disease } \\
\text { (days) before and } \\
\text { after biopsy }\end{array}$}} & \multicolumn{2}{|c|}{ Light microscopy } & \multicolumn{4}{|c|}{ Cytophotometry } \\
\hline & & & & $\begin{array}{l}\text { Hepatocyte* } \\
\text { volume } \\
\text { fraction }\end{array}$ & $\begin{array}{l}\text { Mitotic } \\
\text { index } \\
(\%)\end{array}$ & $\begin{array}{l}\text { Nuclei } \\
\text { scanned } \\
\text { (no.) }\end{array}$ & $\begin{array}{l}\text { Diploid } \\
(\%)\end{array}$ & $\begin{array}{l}\text { S-phase } \\
(\%)\end{array}$ & $\begin{array}{l}\text { Polyploid } \\
(\%)\end{array}$ \\
\hline 1 & $F / 63$ & 34 & 17 & ++ & $0 \cdot 3$ & 150 & 92.6 & 1.81 & $5 \cdot 3$ \\
\hline 2 & $\mathrm{M} / 54$ & 27 & 0 & +++ & $1 \cdot 1$ & 289 & 93.0 & 0.69 & $6 \cdot 2$ \\
\hline 3 & $F / 43$ & 75 & 0 & + & 0.0 & 99 & 94.9 & 0.0 & $5 \cdot 1$ \\
\hline 4 & $F / 76$ & 56 & 13 & $+t$ & $1 \cdot 1$ & 113 & $79 \cdot 5$ & 5.95 & $14 \cdot 1$ \\
\hline 6 & $F / 25$ & 15 & 2 & + & $2 \cdot 5$ & 101 & $57 \cdot 3$ & $10 \cdot 8$ & $32 \cdot 6$ \\
\hline 7 & $F / 32$ & 22 & $\mathbf{0}$ & + & $1 \cdot 2$ & 33 & 100 & 0.0 & 0.0 \\
\hline
\end{tabular}

"Tissue consisting of parenchymal cells: + : less than $33 \%+++: 33-67 \%++++: 67-100 \%$. 
Table 2 Clinical data and regenerative indices of hepatocytes from control patients

\begin{tabular}{|c|c|c|c|c|c|c|c|c|}
\hline \multirow[b]{2}{*}{$\begin{array}{l}\text { Patient } \\
\text { no. }\end{array}$} & \multirow[b]{2}{*}{$\begin{array}{l}\text { Sex/age } \\
(y r)\end{array}$} & \multirow[b]{2}{*}{$\begin{array}{l}\text { Duration of } \\
\text { disease (days) } \\
\text { before biopsy }\end{array}$} & \multicolumn{2}{|l|}{ Light microscopy } & \multicolumn{4}{|c|}{ Cytophotometry } \\
\hline & & & Histological diagnosis & $\begin{array}{l}\text { Mitotic } \\
\text { index }(\%)\end{array}$ & $\begin{array}{l}\text { Nuclei } \\
\text { scanned } \\
\text { (no.) }\end{array}$ & $\begin{array}{l}\text { Diploid } \\
(\%)\end{array}$ & $\begin{array}{l}\text { S-phase } \\
(\%)\end{array}$ & $\begin{array}{l}\text { Polyploid } \\
(\%)\end{array}$ \\
\hline 8 & $F / 46$ & - & Normal & 0 & 222 & $95 \cdot 0$ & 0 & $5 \cdot 0$ \\
\hline 9 & $\mathbf{M} / 27$ & 12 & $\begin{array}{l}\text { Moderate acute } \\
\text { hepatitis }\end{array}$ & $1 \cdot 0$ & 200 & $94 \cdot 5$ & 0 & $5 \cdot 5$ \\
\hline 10 & $\mathrm{~F} / 80$ & 29 & $\begin{array}{l}\text { Moderate acute } \\
\text { hepatitis }\end{array}$ & $1 \cdot 3$ & 210 & $91 \cdot 4$ & $2 \cdot 7$ & $5 \cdot 7$ \\
\hline 11 & $\mathrm{~F} / 56$ & 36 & Severe acute hepatitis & $1 \cdot 6$ & 86 & $95 \cdot 3$ & 0 & $4 \cdot 7$ \\
\hline 12 & $\mathrm{~F} / 49$ & 17 & Severe acute hepatitis & $5 \cdot 5$ & 84 & $78 \cdot 5$ & $15 \cdot 4$ & $6 \cdot 0$ \\
\hline 13 & $\mathrm{~F} / 32$ & 6 & Severe acute hepatitis & $7 \cdot 3$ & 211 & 90.9 & $4 \cdot 7$ & $4 \cdot 3$ \\
\hline 14 & $\mathrm{~F} / 25$ & 12 & Severe acute hepatitis & $4 \cdot 7$ & 201 & $79 \cdot 1$ & $11 \cdot 1$ & $10 \cdot 0$ \\
\hline 15 & $\mathrm{M} / 25$ & 15 & Non-specific changes & 0.19 & 92 & 95.6 & 0 & $4 \cdot 3$ \\
\hline
\end{tabular}

tetraploid nucleus. In order to evaluate this possible error we initially performed measurements on one normal, and one regenerating rat liver. The results are shown in Fig. 1 as frequency-distributions of

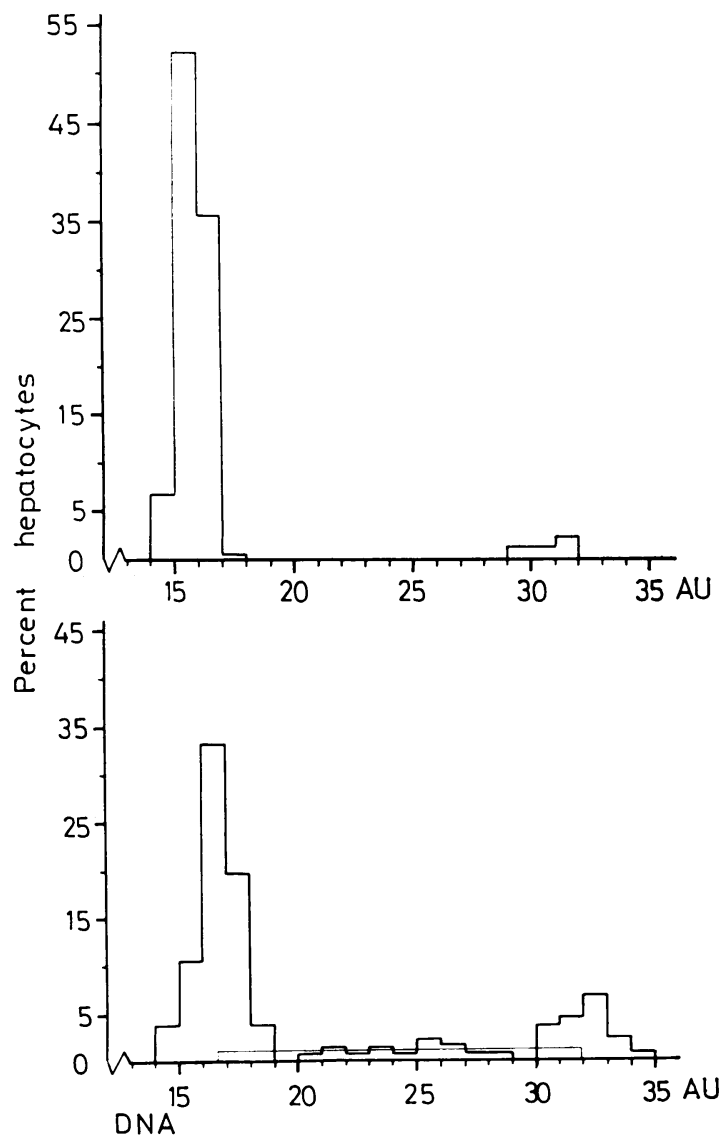

Fig. 2 DNA frequency-histogram of parenchymal liver cells from the normal control (top) and from an acute liver failure patient (no. 5) (bottom). The area below the thin line between the DNA ploidy modes represents the frequency of $S$-phase cells as calculated according to Barfod. ${ }^{1}$
DNA contents. The normal liver showed a bimodal distribution with no left skewness, as would have been the case if sectioned nuclei had been selected for measurement. The coefficient of variation of the DNA content of tetraploid, normal rat hepatocytes was $2 \cdot 1 \%$, corresponding to that of isolated rat liver cells, and slightly above the random measuring error of the UMSP I. ${ }^{\text {? }}$

In the regenerating rat liver the DNA frequencyhistogram of parenchymal cells showed nuclei with DNA contents between di/tetra/ and octaploid values corresponding to $S$-phase nuclei.

We, therefore, conclude that the method used for evaluating the frequency of S-phase nuclei is valid.

\section{Results}

Frequencies of S-phase and polyploid nuclei and mitotic index are shown in Tables 1 and 2. Data from the acute liver failure group (Table 1) show that in all but one patient there is evidence of hepatocyte proliferation-that is, S-phase and/or mitotic cells (Fig. 2). In three patients, two of whom had very few residual hepatocytes (nos. 5 and 6), the percentage of S-phase nuclei is just as high as during liver regeneration after acute hepatitis (Table 2).

In the acute liver failure patients with a high percentage of S-phases there are many polyploid nuclei, but not a comparable increase in mitotic index.

In the patients with acute hepatitis the high percentage of S-phases is associated with a high mitotic index, but not with an increased occurrence of polyploid nuclei.

In this small material there is no obvious association between the presumed aetiology and particular values of the regenerative indices (Tables 1 and 2).

\section{Discussion}

Liver cell proliferation evidenced by DNA synthesis and mitosis was found in all but one patient with 
acute liver failure, particularly in the most severe cases with subtotal liver cell necrosis (nos. 5 and 6). Absence of proliferative activity in one patient (no. 3) may be attributable to treatment with azathioprine ${ }^{8}$ and prednisone. ${ }^{9}$ A comparatively low percentage of S-phases found in three more patients with acute liver failure may be due to the fact that the biopsies were taken immediately after death (nos. 2 and 7) and/or by the presence of severe acute pancreatitis (found at necropsy in patients nos. 1 and 2).

The presence of cells with DNA contents between diploid and tetraploid is per se no proof of ongoing DNA synthesis, as the cells may be arrested in Sphase. This would, however, imply low production of post-synthetic cells-that is, polyploid and mitotic cells. As there are both mitosis and high proportions of polyploid cells in the acute liver failure patients, we conclude that the cells with intermediate DNA values are proliferating cells.

Differences in mitotic index as percentage of S-phases between patients reflect differences in proliferation intensity only in so far as the duration of mitosis and DNA synthesis is the same. We have no data on the duration of cell cycle phases from our patients, nor relevant data from the literature, and must assume that variations in phase durations are responsible for some of the differences between patients. For instance, the relatively high proportion of polyploids in patients with acute liver failure (nos. 4 and 6) compared with controls with a similar percentage of S-phases (nos. 12 and 14) may be explained by such a mechanism.

This demonstration of liver cell proliferation in patients with acute liver failure is, to our knowledge, the first evidence that the poor prognosis of this condition is not due to absence of regeneration. From our data it appears that some fatally ill acute liver failure patients have just as vigorous a regenerative response as cases of clinically benign hepatitis. These observations are helpful when attempting to apply the experience gained in animal studies to the clinical setting.

In experiments on eviscerated and partially hepatectomised animals it was shown that insulin and glucagon are promotors, but not initiators, of liver regeneration. ${ }^{1}$ As regeneration is initiated in all patients with acute liver failure, but sluggish in some, the latter may benefit from administration of exogenous insulin and glucagon. Interestingly, in our material two cases of acute liver failure with low regenerative indices had acute pancreatitis and may have had impaired insulin and glucagon secretion.

The results of Junge and Creutzfeld ${ }^{10}$ showed that it was not possible to accelerate regeneration by additional exogenous insulin and glucagon in partially hepatectomised rats with undisturbed insulin and glucagon secretion. By analogy a higher rate of proliferation cannot be expected after insulin and glucagon administration in those patients with acute liver failure who have a great number of S-phase cells and mitoses.

The number of cells in an organ depends on the rate of cell destruction and of cell production. The fact that the patients with acute liver failure die with a small liver cell mass despite demonstrable regeneration implies that the rate of cell necrosis has been higher than that of cell renewal. Inhibiting liver cell necrosis is therefore at least as important as promoting regeneration in the treatment of acute liver failure. It is intriguing that insulin and glucagon, if given within hours after inoculation seem to have both effects in experimental murine hepatitis. ${ }^{11}$

Mrs Karen Pedersen is thanked for expert technical assistance. Dr Milena Milandri was supported by a scholarship from the Danish Ministry of Education. This work was supported by P. Carl Petersen Foundation Grant No. B 1014.

\section{References}

${ }^{1}$ Bucher NLR, Swaffield MN. Regulation of hepatic regeneration in rats by synergistic action of insulin and glucagon. Proc Nate Acad Sci 1975; 72: 1157-60.

${ }^{2}$ Starzl TE, Porter KA, Putnam CW. Intraportal insulin protects from the liver injury of portacaval shunt in dogs. Lancet 1975; 2: 1241-2.

${ }^{3}$ Starzl TW, Watanabe K, Porter KA, Putnam CW. Effects of insulin, glucagon, and insulin/glucagon in fusions on liver morphology and cell division after complete portacaval shunt in dogs. Lancet 1976; 1: 821-5.

${ }^{4}$ Sherlock S. Portal venous 'goodies' and fulminant viral hepatitis. $N$ Engl J Med 1976; 295: 1535-6.

${ }^{5}$ Gaub J, Auer G, Zetterberg A. Quantitative cytochemical aspects of a combined feulgen-naphthol yellow $\mathbf{S}$ staining procedure for the simultaneous determination of nuclear and cytoplasmic proteins and DNA in mammalian cells. Exp Cell Res 1975; 92: 323-32.

${ }^{6}$ Barfod NM. Flow microfluorometric estimation of G1 and G2 chalone inhibition of the JB-1 tumour cell cycle in vitro. Exp Cell Res 1977; 110: 225-36.

${ }^{7}$ Gaub J. Feulgen-Naphthol yellow S cytophotometry of liver cells: the effect of formaldehyde induced shrinkage on nuclear Naphthol yellow $\mathbf{S}$ binding. Histochemistry 1976; 49: 293-301.

${ }^{8}$ Klinge $\mathrm{O}$, Heine WD, Röschlau T. Influences of cytostatic and immunosuppressive drugs on liver regeneration. In: Lesch R, Reutter W, eds. Liver regeneration after experimental injury. New York, Stratton, 1973: $75-84$.

${ }^{9}$ Roberts KB, Florey HW, Joklik WK. The influence of cortisone on cell division. $Q J$ Exp Physiol 1952; 37 239-57. 
${ }^{10} J u n g e$ U, Creutzfeld W. Hepatotrophic effects of pancreatic and gastrointestinal hormones in the rat in vivo and in vitro. In: Hepatotrophic factors, Ciba Foundation Symposium 55. Amsterdam: Elsevier,
1978: 269-83.

${ }^{11}$ Farivar M, Wands JR, Isselbacher KJ, Bucher NLR. Effect of insulin and glucagon on fulminant murine hepatitis. $N$ Engl J Med 1976; 295: 1517-9. 